medRxiv preprint doi: https://doi.org/10.1101/2020.04.19.20071936; this version posted April 23, 2020. The copyright holder for this preprint (which was not certified by peer review) is the author/funder, who has granted medRxiv a license to display the preprint in perpetuity.

It is made available under a CC-BY 4.0 International license .

Influence of blood pressure on pneumonia risk: Epidemiological association and Mendelian randomisation in the UK Biobank

Seyedeh M. Zekavat BS (1-4; ORCID: 0000-0003-4026-8944), Michael Honigberg MD MPP (36), James Pirruccello MD (3-6), Puja Kohli MD MMSc $(5,7)$, Elizabeth W. Karlson MD $(4,5,8)$, Christopher Newton-Cheh MD MPH (3-6), Hongyu Zhao PhD (2,9), Pradeep Natarajan MD MMSc (3-6; ORCID: 0000-0001-8402-7435)

1. Yale School of Medicine, New Haven, CT;

2. Computational Biology \& Bioinformatics Program, Yale University, New Haven, CT;

3. Program in Medical and Population Genetics, Broad Institute of MIT and Harvard, Cambridge, MA;

4. Center for Genomic Medicine, Massachusetts General Hospital, Boston, MA;

5. Department of Medicine, Harvard Medical School, Boston, MA;

6. Cardiovascular Research Center, Massachusetts General Hospital, Boston, MA;

7. Division of Pulmonary and Critical Care Medicine, Massachusetts General Hospital, Boston, MA;

8. Division of Allergy, Immunology, and Rheumatology, Brigham and Women's Hospital, Boston, MA;

9. Department of Biostatistics, Yale School of Public Health, New Haven, CT

Please address correspondence to:

Pradeep Natarajan, MD MMSc

pnatarajan@mgh.harvard.edu

185 Cambridge Street, CPZN 3.184, Boston, MA 02114

Tel: 617-724-3526

Fax: 617-726-2203

Twitter: @pnatarajanmd

Abstract word count: 258

Main text word count: 3,878

Main display item count: 4

Reference count: 52

Key words: Pneumonia, Respiratory Infections, Pulmonary Function Tests, Hypertension, Blood Pressure, Genetic Epidemiology, Population Genetics 
medRxiv preprint doi: https://doi.org/10.1101/2020.04.19.20071936; this version posted April 23, 2020. The copyright holder for this preprint (which was not certified by peer review) is the author/funder, who has granted medRxiv a license to display the preprint in perpetuity.

It is made available under a CC-BY 4.0 International license.

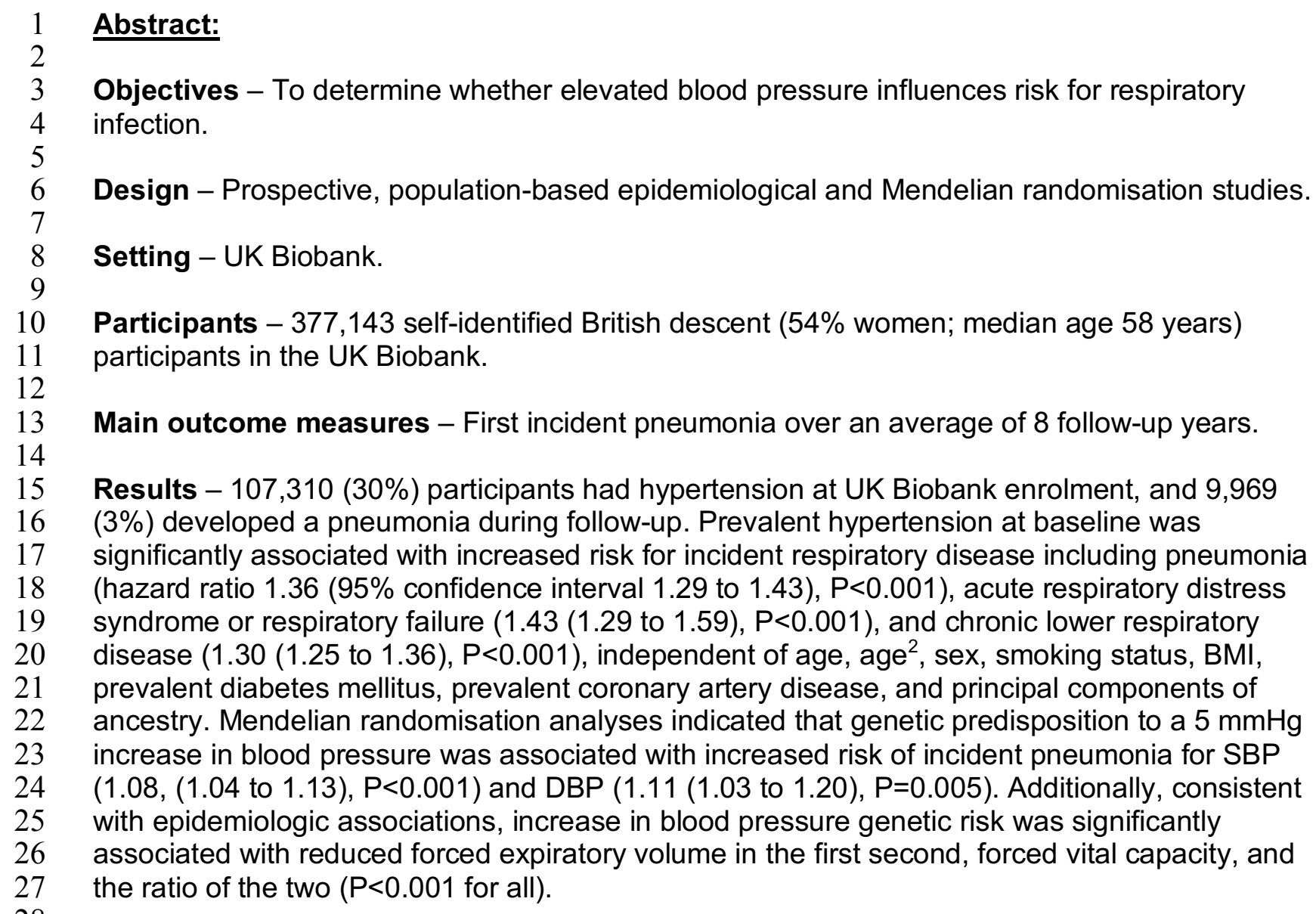

Conclusions - These results strongly suggest that elevated blood pressure independently increases risk for pneumonia and reduces pulmonary function. Maintaining adequate blood pressure control, in addition to other measures, may reduce risk for pneumonia. Whether the present findings are generalizable to novel coronavirus disease 2019 (COVID-19) require 33 further study. 
medRxiv preprint doi: https://doi.org/10.1101/2020.04.19.20071936; this version posted April 23, 2020. The copyright holder for this preprint (which was not certified by peer review) is the author/funder, who has granted medRxiv a license to display the preprint in perpetuity.

\section{Summary Box:}

Section 1: What is already known on this topic

- Hypertension has been associated with pneumonia in small observational studies.

- Based on early epidemiologic analyses, hypertension is described as a risk factor for SARS-CoV-2 infection and associated novel coronavirus disease 2019 (COVID-19).

- The influence of hypertension on pneumonia risk is difficult to assess in traditional observational studies.

\section{Section 2: What this study adds}

- Our pre-COVID-19 analyses are consistent with a causal relationship between increased blood pressure and increased risk for incident respiratory infections, as well as between increased blood pressure and reduced pulmonary function.

- These results support hypertension as a pneumonia risk factor; efforts to optimize blood pressure may reduce risk for pneumonia. 
medRxiv preprint doi: https://doi.org/10.1101/2020.04.19.20071936; this version posted April 23, 2020. The copyright holder for this preprint (which was not certified by peer review) is the author/funder, who has granted medRxiv a license to display the preprint in perpetuity.

It is made available under a CC-BY 4.0 International license .

\section{Introduction}

3 Hypertension is a highly prevalent, modifiable risk factor for cardiovascular disease and

4 mortality ${ }^{1}$. Epidemiologic analyses have correlated hypertension with pneumonia risk in small

5 studies ${ }^{23}$. Whether this represents a direct consequence of hypertension or influence of co-

6 morbid risk factors such as age, diabetes mellitus, air pollution, or smoking is unclear.

8 Hypertension has emerged as one of the most well-recognized risk factors for developing novel 9 coronavirus disease 2019 (COVID-19) from SARS-CoV-2 infection ${ }^{4-7}$. In particular, patients with

10 COVID-19 who develop acute respiratory distress syndrome (ARDS) are particularly enriched

11 for hypertension ${ }^{7}$. Angiotensin converting enzyme (ACE) is an endogenous regulator of blood

12 pressure that is highly expressed in the lung and has been linked to risk for acute respiratory

13 distress syndrome (ARDS) ${ }^{89}$. ACE2, a homolog and endogenous counter-regulator of ACE, is

14 expressed in a subset of type II alveolar cells and is an important facilitator of cell entry by

15 SARS-CoV-2 ${ }^{8-10}$. ACE2 has also been implicated in lung injury related to other respiratory

16 viruses and bacterial pathogens ${ }^{11-13}$. While professional societies have encouraged patients to

17 remain on ACE inhibitors during the present pandemic, recommendations were largely made in

18 the absence of robust human data.

20 Although epidemiologic analyses support a plausible causal relationship between blood

21 pressure regulation and respiratory infection risk, confounding from comorbid conditions limit

22 such inference. Importantly, comorbid factors such as advanced age, diabetes mellitus, and

23 cardiovascular disease have also been described as independent risk factors for pneumonia

24 previously as well as for COVID-19. Mendelian randomisation is a statistical approach using

25 genetic proxies for an exposure as opposed to the exposure itself to mitigate risks for

26 confounding facilitating more robust causal inference ${ }^{14}$. Blood pressure is a highly heritable trait 
medRxiv preprint doi: https://doi.org/10.1101/2020.04.19.20071936; this version posted April 23, 2020. The copyright holder for this preprint (which was not certified by peer review) is the author/funder, who has granted medRxiv a license to display the preprint in perpetuity.

It is made available under a CC-BY 4.0 International license .

1 with several known associated genomic loci that may serve as a robust aggregated genetic

2 proxy for Mendelian randomization ${ }^{15}$.

4 In the UK Biobank prior to the COVID-19 pandemic, we (1) estimate the epidemiologic

5 association of hypertension with incident pneumonia risk and indices of pulmonary function, and

6 (2) apply Mendelian randomisation to test the hypothesis that blood pressure independently

7 causally influences risks for pneumonia and reduced pulmonary function.

9 Methods

\section{UK Biobank}

13 Individual-level genomic data and longitudinal phenotypic data from the UK Biobank, a large-

14 scale population-based cohort with genotype and phenotype data in approximately 500,000

15 volunteer participants recruited from 2006-2010 was used ${ }^{16}$. Baseline assessments were

16 conducted at 22 assessment centres across the UK using touch screen questionnaire, computer

17 assisted verbal interview, physical tests, and sample collection including for DNA. Additional

18 details regarding the study protocol are described online (www.ukbiobank.ac.uk). Of 488,377

19 individuals genotyped in the UK Biobank, we used data for 377,143 participants with white

20 British ancestry consenting to genetic analyses, with genotypic-phenotypic sex concordance,

21 without sex aneuploidy, and one from each pair of $1^{\text {st }}$ or $2^{\text {nd }}$ degree relatives selected randomly.

22 Participants provided informed consent as previously described. Secondary use of the data was

23 approved by the Massachusetts General Hospital institutional review board (protocol

24 2013P001840) and facilitated through UK Biobank Application 7089. 
medRxiv preprint doi: https://doi.org/10.1101/2020.04.19.20071936; this version posted April 23, 2020. The copyright holder for this preprint (which was not certified by peer review) is the author/funder, who has granted medRxiv a license to display the preprint in perpetuity.

It is made available under a CC-BY 4.0 International license.

1 Genome-wide genotyping was previously performed in the UK Biobank using two genotyping

2 arrays sharing 95\% of marker content: Applied Biosystems UK BiLEVE Axiom Array $(807,411$

3 markers in 49,950 participants) and Applied Biosystems UK Biobank Axiom Array (825,927

4 markers in 438,427 participants) both by Affymetrix (Santa Clara, CA) ${ }^{16}$. Variants used in the

5 present analysis include those also imputed using the Haplotype Reference Consortium

6 reference panel of up to 39 million single nucleotide polymorphisms (SNPs) ${ }^{17}{ }^{18}$. Poor quality

7 variants and genotypes were filtered as previously described ${ }^{16}$.

\section{Phenotypes}

10 Hypertension, covariates, and medication measures

11 Disease definitions for hypertension and clinical disease covariates are as previously

12 described $^{19}$. In brief, hypertension was defined by self-reported hypertension and billing codes

13 for essential hypertension, hypertensive disease with and without heart failure, hypertensive

14 heart and renal diseases, and secondary hypertension. Prevalent coronary artery disease

15 (CAD), was defined by billing codes for heart attack, angina pectoris, unstable angina,

16 myocardial infarction, coronary atherosclerosis, coronary artery revascularization, and other

17 acute, subacute, and chronic forms of ischemic heart disease, or with self-reported angina,

18 heart attack/myocardial infarction, coronary angioplasty +/- stent, or coronary artery bypass

19 graft (CABG) surgery. Diabetes mellitus included billing codes for type 1, type 2, and gestational

20 diabetes mellitus, as well as self-reported diabetes mellitus and insulin use.

21 Blood pressure medications were characterized by medication type into angiotensin converting

22 enzyme inhibitors (ACEi), angiotensin receptor blockers (ARB), or other medication. The list of

23 ACEi and ARBs considered in UK Biobank participants is provided in Supplementary Table 1. 
medRxiv preprint doi: https://doi.org/10.1101/2020.04.19.20071936; this version posted April 23, 2020. The copyright holder for this preprint (which was not certified by peer review) is the author/funder, who has granted medRxiv a license to display the preprint in perpetuity.

It is made available under a CC-BY 4.0 International license .

1 Patients taking at least one ACEi were included in the ACEi category, patients taking no ACEi

2 but at least one ARB were included in the ARB category, and patients who reported that they

3 were taking a blood pressure medication (via UK Biobank Field IDs 6153 and 6177) but were

4 not taking an ACEi or ARB were included in the 'other' category.

$6 \quad$ Respiratory outcomes

7 Clinical disease definitions for our primary outcome (pneumonia) and related respiratory

8 outcomes are detailed in Supplementary Table 2. In summary, these included respiratory

9 diseases using the first reported occurrences of respiratory system disorders in Category 2410

10 as categorized by the UK Biobank (http://biobank.ndph.ox.ac.uk/showcase/label.cgi?id=2410)

11 which maps primary care data, ICD-9 and ICD-10 codes from hospital inpatient data, ICD-10

12 codes in death register records, and self-reported medical conditions reported at the baseline, to

13 ICD-10 codes. For each set of phenotypes, the time to first incident event after baseline

14 examination in individuals free of prevalent history of respiratory system disorder was used.

15 Pneumonia includes viral, bacterial, and unspecified aetiologies (J12-J18). Influenza or viral

16 pneumonia includes confirmed or suspected influenza or viral pneumonia (J09-J12). The acute

17 upper respiratory infections category includes acute nasopharyngitis, sinusitis, pharyngitis,

18 tonsillitis, laryngitis, tracheitis, croup, epiglottitis, or upper respiratory infections of multiple and

19 unspecified sites (J00-J06). The other acute lower respiratory infections category includes acute

20 bronchitis, bronchiolitis, or unspecified acute lower respiratory infections (J20-J22). The other

21 diseases of the upper respiratory tract category includes rhinitis, nasopharyngitis, pharyngitis,

22 chronic sinusitis, nasal polyps, other disorders of the nose and nasal sinuses, chronic diseases

23 of the tonsils and adenoids, peritonsillar abscess, chronic laryngitis, laryngotracheitis, diseases

24 of the vocal cords and larynx, or other diseases of the upper respiratory tract (J30-J39). Chronic

25 lower respiratory diseases include bronchitis, emphysema, chronic obstructive pulmonary

26 disease, asthma, bronchiectasis (J40-J47). Other interstitial respiratory diseases refer to acute 
medRxiv preprint doi: https://doi.org/10.1101/2020.04.19.20071936; this version posted April 23, 2020. The copyright holder for this preprint (which was not certified by peer review) is the author/funder, who has granted medRxiv a license to display the preprint in perpetuity.

It is made available under a CC-BY 4.0 International license .

1 respiratory distress syndrome (ARDS), pulmonary oedema, or other interstitial pulmonary

2 diseases (J80, J81, J84). Respiratory failure refers to J96 (respiratory failure not elsewhere

3 classified).

4

5 Quantitative phenotypes included best-measure pulmonary function tests from spirometry using

6 a Vitalograph Pneumotrac 6800 (Buckingham, United Kingdom), including forced expiratory

7 volume in the first second (FEV1), forced vital capacity (FVC), and the ratio of these two

8 measurements (FEV1/FVC). For each individual measurement, extreme outliers were

9 determined and filtered by adjusting the traditional box and whisker upper and lower bounds

10 and accounting for skewness in the phenotypic data identified using the Robustbase package in

$11 \mathrm{R}$ (setting range=3) (https://cran.r-project.org/web/packages/robustbase/robustbase.pdf).

12 Phenotypes were then inverse rank normalized to mean 0 and standard deviation (SD) 1 for

13 analysis.

14

15 Statistical methods

17 Association between prevalent hypertension and respiratory conditions in the UK Biobank

18 Phenotypic association of prevalent hypertension with incident respiratory diseases and with

19 pulmonary function tests was performed using Cox proportional hazards models among

20 individuals without the corresponding prevalent condition in R (version 3.5, R Foundation,

21 Vienna, Austria). The proportional hazards assumption was assessed by Schoenfeld residuals

22 and was satisfied. The sparsely adjusted model included age, age ${ }^{2}$, sex, smoking status

23 (current, previous, or never smoker), and the first ten principal components of ancestry. The

24 fully adjusted model additionally incorporated body-mass index (BMI), prevalent diabetes

25 mellitus, and prevalent coronary artery disease. 
medRxiv preprint doi: https://doi.org/10.1101/2020.04.19.20071936; this version posted April 23, 2020. The copyright holder for this preprint (which was not certified by peer review) is the author/funder, who has granted medRxiv a license to display the preprint in perpetuity.

It is made available under a CC-BY 4.0 International license .

1 Genetic instruments for blood pressure and association analyses

2 One-sample Mendelian randomisation was performed in the UK Biobank by associating inverse-

3 rank normalized systolic blood pressure and diastolic blood pressure polygenic risk scores (SBP

4 PRS, DBP PRS) with incident respiratory disease phenotypes. The 75 variants comprising each

5 genetic instrument (Supplementary Tables 3, 4) were determined by identifying genome-wide

6 significant $\left(P<5 \times 10^{-8}\right)$, largely uncorrelated (linkage disequilibrium $\left.r^{2}<0.2\right)$ variants for each

7 phenotype from the International Consortium for Blood Pressure (ICBP) GWAS summary

8 statistics across 299,024 individuals among 77 cohorts excluding the UK Biobank ${ }^{15}$.

10 Additive polygenic risk scores were determined as such: $\sum_{i=1}^{75} \operatorname{Beta} \times S N P_{i j}$, where Beta is the

11 weight for each allele of $S N P_{i}$ from the ICBP GWAS summary statistics, and $S N P_{i j}$ is the

12 number of alleles (i.e., 0,1 , or 2 ) for $S N P_{i}$ in participant $j$ in the UK Biobank. To confirm that the

13 SBP PRS and DBP PRS were strong instruments, we assessed their associations with SBP and

14 DBP, adjusted for blood pressure medications by adding 15 and $10 \mathrm{mmHg}$ to SBP and DBP,

15 respectively, as previously done ${ }^{2021}$. Each genetic instrument was validated against its

16 exposure by calculating an F-statistic derived from unadjusted linear regression of the exposure

17 against its PRS. An F-statistic greater than 10 indicates low risk of weak-instrument bias.

19 Additional sensitivity analyses tested associations between each PRS and potential social and

20 lifestyle confounders including the Townsend deprivation index for socioeconomic status

21 estimation ${ }^{22}$, smoking status (Field ID 20116), alcohol intake frequency (Filed ID 1558),

22 vegetable serving intake (Field ID 104060), handfuls of sweet intake (Field ID 102330),

23 significant life stressor over the past two years (Field ID 6145), and exercise frequency (Field ID

24 3637). 
medRxiv preprint doi: https://doi.org/10.1101/2020.04.19.20071936; this version posted April 23, 2020. The copyright holder for this preprint (which was not certified by peer review) is the author/funder, who has granted medRxiv a license to display the preprint in perpetuity.

It is made available under a CC-BY 4.0 International license .

1 Association analysis of the SBP and DBP PRS with incident respiratory diseases was

2 performed using Cox proportional hazards models in R (version 3.5, R Foundation, Vienna,

3 Austria), adjusting for age, age ${ }^{2}$, sex, smoking status, and the first ten principal components of

4 ancestry. The proportional hazards assumption was assessed by Schoenfeld residuals and was

5 satisfied. Association analyses between the SBP and DBP PRS and pulmonary function tests

6 was performed using a generalized linear model adjusted for the same covariates.

8 Association of the 75 variants for each PRS with both prevalent and incident pneumonia was

9 performed using a logistic regression Wald test in Hail-0.2, adjusting for age, age ${ }^{2}$, sex, smoking

10 status, the first ten principal components of ancestry, and genotype array. Using these

11 associations, two-sample Mendelian randomization was performed using the ICBP-derived SBP

12 and DBP genetic instruments as exposures and the respective effects of each variant on

13 pneumonia in the UK Biobank as outcomes. Two-sample Mendelian randomization was

14 performed using both the robust, penalized inverse variance weighted (IVW) method from the

15 MendelianRandomization package in $\mathrm{R}^{23} 24$, as well as robust adjusted profile score (MR-

16 RAPS $)^{25}$ for comparison. IVW 2-sample Mendelian randomization uses a weighted linear

17 regression of the ratio of the SNP effects on the outcomes to the SNP effects on the risk factor,

18 without using an intercept term. MR-RAPS models the systematic pleiotropy using a random

19 effects model to create a robust adjusted profile score. We additionally use the TwoSampleMR

20 package in $\mathrm{R}$ (https://mrcieu.github.io/TwoSampleMR/index.html) to perform multiple sensitivity

21 analyses including heterogeneity tests, the MR Egger intercept test for horizontal pleiotropy, and

22 leave-one-out analyses to determine if there is a single variant driving the genetic association.

\section{$24 \quad$ Results}

\section{Baseline characteristics}


medRxiv preprint doi: https://doi.org/10.1101/2020.04.19.20071936; this version posted April 23, 2020. The copyright holder for this preprint (which was not certified by peer review) is the author/funder, who has granted medRxiv a license to display the preprint in perpetuity.

It is made available under a CC-BY 4.0 International license .

2 A total of 377,143 genotyped individuals in the UK Biobank passed quality control criteria.

3 Among these individuals, median age was 58 [interquartile range 51-63] years, 202,369 (53.7\%)

4 were female, 18,943 (5.0\%) had diabetes mellitus, 107,310 (29.7\%) had hypertension, and

$520,825(5.7 \%)$ had coronary artery disease. $170,713(45.4 \%)$ of individuals were prior or current

6 smokers, and 85,565 (22.6\%) of individuals were on antihypertensive medications

7 (Supplementary Table 5).

8

9 Across an average follow-up time of 8 years (IQR 7-11 years), 9,969 (2.6\%) individuals

10 developed a pneumonia, 11,972 (3.3\%) developed influenza or pneumonia, $18,172(5.5 \%)$

11 developed an acute upper respiratory infection, 21,734 (6.2\%) developed other lower respiratory

12 infection (e.g., bronchitis), 12,963 (4.0\%) developed a chronic lower respiratory disease, 1,792

$13(0.5 \%)$ developed other interstitial respiratory disease, and 2,621 $(0.7 \%)$ developed ARDS or

14 respiratory failure.

Epidemiological association of prevalent hypertension with incident respiratory disease

18 Prevalent hypertension was independently associated with risk of incident respiratory disease

19 including pneumonia (1.36 (1.29 to 1.43$), \mathrm{P}<0.001)$, chronic lower respiratory disease $(11.30$,

20 (1.25 to 1.36), $P<0.001$ ), influenza or pneumonia (1.31 (1.25 to 1.37), $P<0.001)$, ARDS or

21 pulmonary failure (1.43 (1.29 to 1.59$), P<0.001)$, other lower respiratory infections (1.15 (1.37 to

22 1.45), $P<0.001$ ), other acute upper respiratory infection (1.06 (1.11 to 1.19), $P=0.002$ ), other

23 interstitial respiratory disease (1.16 (1.02 to 1.31), $\mathrm{P}=0.022)$, and influenza or viral pneumonia

24 (1.12 (1.01 to 1.23), $P=0.032$ ), after adjustment for age, age ${ }^{2}$, sex, smoking status, BMI,

25 prevalent diabetes, prevalent coronary artery disease, and the first ten principal components of

26 population stratification (Figure 1). 
medRxiv preprint doi: https://doi.org/10.1101/2020.04.19.20071936; this version posted April 23, 2020. The copyright holder for this preprint (which was not certified by peer review) is the author/funder, who has granted medRxiv a license to display the preprint in perpetuity.

It is made available under a CC-BY 4.0 International license .

2 Epidemiological association of antihypertensive use with incident pneumonia

4 Among the participants, ACEi were prescribed for 37,865 (10.0\%), ARBs for 13,207 (3.5\%), and

5 other antihypertensives for 34,493 (9.1\%). Prescriptions for ACEi, ARBs, or other

6 antihypertensive medicines were similarly associated with increased risk for incident pneumonia

7 (Figure 2). However, upon further adjustment for prevalent hypertension status, we did not

8 observe an association of these medication classes with risk for pneumonia.

10 Genetic association of blood pressure with incident respiratory disease

12 We first used one-sample Mendelian randomisation to determine whether a genetic

13 predisposition to increased blood pressure is associated with increased risk for incident

14 pneumonia as well as other respiratory diseases.

16 Our SBP and DBP genetic instruments each consisted of 75 independent variants (linkage

17 disequilibrium $r^{2}<0.2$ ) that were genome-wide significant among 299,024 individuals external to

18 the UK Biobank from the International Consortium for Blood Pressure Genomics. The resulting

19 PRS for SBP and, separately, for DBP were significantly associated with their respective

20 phenotypes in the UK Biobank, with each SD increase in the SBP PRS increasing SBP by

$212.26 \mathrm{mmHg}$ (F-statistic: 4176) and each SD increase in the DBP PRS increasing DBP by 1.32

$22 \mathrm{mmHg}$ (F-statistic: 4785) (Supplementary Table 6). 53 SNPs (or SNPs in perfect linkage

23 disequilibrium) were common to both SBP and DBP PRS. Sensitivity analyses were performed

24 to assess for potential social and lifestyle confounders associating with the SBP and DBP PRS,

25 and found no significant associations between the PRS and the Townsend deprivation index for

26 socioeconomic status estimation, smoking status, alcohol intake frequency, vegetable intake, 
medRxiv preprint doi: https://doi.org/10.1101/2020.04.19.20071936; this version posted April 23, 2020. The copyright holder for this preprint (which was not certified by peer review) is the author/funder, who has granted medRxiv a license to display the preprint in perpetuity.

It is made available under a CC-BY 4.0 International license .

1 sweet intake, significant life stressor in the past two years, or exercise frequency

2 (Supplemental Table 7).

4 Each SD increase in the SBP PRS was associated with a significant increased risk of incident

5 pneumonia (1.04 (1.02 to 1.06), $\mathrm{P}<0.001)$, influenza or pneumonia (1.03 (1.01 to 1.05$)$,

$6 \mathrm{P}=0.003)$, and other lower respiratory infection (1.02 (1.00 to 1.03), $P=0.029)$. Each SD increase

7 in the DBP PRS was also associated with an increased risk of incident pneumonia (1.03, (1.01

8 to 1.05), $P=0.005)$, and other lower respiratory infections (1.02 (1.00 to 1.03), $P=0.012$ ) (Figure

9 3). Accordingly, each $5 \mathrm{mmHg}$ increase in SBP conferred by the SBP PRS was associated with

10 a significant increased risk of incident pneumonia incident pneumonia (1.08 (1.04 to 1.13),

$11 \mathrm{P}<0.001$ ), influenza or pneumonia (1.06 (1.02 to 1.11$), \mathrm{P}=0.003)$, and other lower respiratory

12 infection (1.03 (1.00 to 1.06), $\mathrm{P}=0.029)$. Additionally, each $5 \mathrm{mmHg}$ increase in DBP conferred

13 by the DBP PRS was associated with an increased risk of incident pneumonia $(1.11,(1.03$ to

14 1.20), $P=0.005)$, and other lower respiratory infections (1.07 (1.01 to 1.12), $P=0.012)$.

16 Two-sample Mendelian randomization was additionally performed using pneumonia association

17 statistics, from the UK Biobank, for the 75 variants, with blood pressure summary statistics

18 external to the UK Biobank as above. Both penalized, robust, inverse-variance weighted (IVW)

19 and robust adjusted profile score (MR-RAPS) $)^{25}$ methods produced similarly significant results

20 (Supplementary Table 8). Sensitivity analyses were additionally performed to analyse the

21 robustness of the results. Across both SBP and DBP genetic instruments, the IVW

22 heterogeneity test and the MR Egger regression intercept term are both insignificant, suggesting

23 negligible contribution of heterogeneity and directional horizontal pleiotropy (Supplementary

24 Table 8). Additionally, the Steiger directionality test ${ }^{26}$ suggests the correct causal direction of

25 blood pressure on pneumonia. Lastly, leave-one-out analyses was additionally performed,

26 suggesting that no single SNP drives the observed association (Supplementary Figure 1). 
medRxiv preprint doi: https://doi.org/10.1101/2020.04.19.20071936; this version posted April 23, 2020. The copyright holder for this preprint (which was not certified by peer review) is the author/funder, who has granted medRxiv a license to display the preprint in perpetuity.

It is made available under a CC-BY 4.0 International license .

1 Variants previously described to influence ACE expression in the lung (rs145126552,

2 rs4277405) or kidney (rs6504163) in GTEx ${ }^{27}$, were not individually associated with pneumonia

3 risk $(P>0.05)$.

5 Epidemiological association of prevalent hypertension with pulmonary function tests

7 Secondary analyses identified significant associations between prevalent hypertension and

8 reduced pulmonary function tests (FEV1: -0.088 SD (-0.09 to -0.08$), P<0.001$; FVC: -0.85 SD (-

90.09 to -0.08$), \mathrm{P}<0.001$; FEV1/FVC: -0.013 SD (-0.02 to -0.01$), \mathrm{P}<0.001)$, independent of age,

10 age $^{2}$, sex, smoking status, body mass index, prevalent coronary artery disease, prevalent

11 diabetes mellitus, and the first ten principal components of ancestry (Figure 4A).

Genetic association of blood pressure with pulmonary function tests

15 Each SD increase in SBP PRS was significantly associated with reduced pulmonary function

16 tests (FEV1: -0.007 SD (-0.01 to -0.005$)$, P<0.001; FVC: -0.003 SD (-0.005 to -0.001$)$,

$17 \mathrm{P}=5.91 \times 10^{-3}$; FEV1/FVC: $-0.014 \mathrm{SD},(-0.017$ to -0.011$\left.), \mathrm{P}<0.001\right)$. Similar associations were

18 identified for between DBP PRS and pulmonary function tests (FEV1: -0.005 SD(-0.008 to -

19 0.003), $P<0.001$; FVC: -0.003 SD (-0.005 to 0), P=0.02; FEV1/FVC: -0.009 SD, (-0.013 to -

20 0.006), $P<0.001)$ (Figure 4B).

\section{Discussion}

24 In a large, prospective, population-based cohort, we show that prevalent hypertension is a risk

25 factor for incident pneumonia, lower respiratory infections, ARDS or respiratory failure, as well

26 as many other respiratory diseases. Additionally, our epidemiological analyses also 
medRxiv preprint doi: https://doi.org/10.1101/2020.04.19.20071936; this version posted April 23, 2020. The copyright holder for this preprint (which was not certified by peer review) is the author/funder, who has granted medRxiv a license to display the preprint in perpetuity.

It is made available under a CC-BY 4.0 International license .

1 demonstrate an association between prevalent hypertension and increased pulmonary

2 obstruction as indicated by reduced FEV1/FVC. Our Mendelian randomisation studies imply that

3 the relationship between increased blood pressure with increased risk for pneumonia as well as

4 reduced pulmonary function may be causal.

6 Our findings may have important implications for the prevention of pneumonia. First, our study

7 establishes that hypertension is an important independent risk factor for the development of

8 pneumonia. Our observation is consistent with prior unadjusted estimates in retrospective

9 analyses ${ }^{228}$. Although significantly associated, the effect of hypertension adjusted for important

10 confounders on future risk for pneumonia is more moderate, as anticipated. Furthermore, our

11 genetic analyses are consistent with a causal relationship between blood pressure and

12 pneumonia. Hypertension has been proposed to promote key factors which may predispose to

13 infection via several potential mechanisms. (1) Hypertensive stimuli promote dysregulation of

14 the adaptive immune response. Chronic angiotensin II infusions in mice increase markers of T

15 lymphocyte activation and perivascular adipose infiltration ${ }^{29}$. Additional murine studies have

16 indicated that monocytes and neutrophils may be key factors in angiotensin II-mediated

17 hypertension and resultant vascular dysfunction ${ }^{30} 31$. A recent Mendelian randomisation study

18 supported a causal relationship between blood pressure and subsequent alteration in

19 neutrophil, monocyte, and eosinophil indices ${ }^{32}$. (2) Endothelial dysfunction as a consequence of

20 hypertension may promote infection. Dysregulation of nitric oxide release and signalling in

21 murine models of pulmonary inflammation leads to exacerbated lung injury ${ }^{33}$. Furthermore,

22 superoxides generated from endothelial NADPH oxidase may play a role in exacerbating

23 influenza-associated lung injury in experimental models ${ }^{34}$.

25 Second, in addition immunologic and vascular effects, blood pressure elevations may result in

26 pulmonary function alterations predisposing to the development of pneumonia. Our Mendelian 
medRxiv preprint doi: https://doi.org/10.1101/2020.04.19.20071936; this version posted April 23, 2020. The copyright holder for this preprint (which was not certified by peer review) is the author/funder, who has granted medRxiv a license to display the preprint in perpetuity.

It is made available under a CC-BY 4.0 International license .

1 randomisation analyses with pulmonary function tests support a causal association between

2 increased blood pressure and indices of increased pulmonary obstruction as indicated by

3 reduced FEV1/FVC. Several prior studies have linked hypertension with decreased

4 performance on pulmonary function tests, reduced lung function, and increased pulmonary

5 obstruction ${ }^{35-37}$. Chronic obstructive pulmonary disease (COPD) is a well-established risk factor

6 for pneumonia, and is co-morbid with several cardiovascular diseases and risk factors including

7 hypertension ${ }^{38}$. Our study extends these observations to show that increased blood pressure

8 may causally lead to increased pulmonary obstruction representing a putative mechanism

9 toward heightened pneumonia risk. Together, these studies and others suggest several

10 mechanisms which may link hypertension and pulmonary obstruction: 1) both may involve

11 physiological degradation of arterial and airway elasticity $\left.{ }^{37}, 2\right)$ endothelial and vascular

12 dysfunction may also influence pulmonary vascular endothelial cells and lead to pulmonary

13 vascular dysfunction resulting in lung tissue destruction and airway obstruction ${ }^{40}$, and 3 )

14 systemic inflammation associated with hypertension may additionally alter pulmonary function ${ }^{41}$

1532.

17 Third, since our results are consistent with a causal relationship between blood pressure and

18 pneumonia risk, blood pressure optimization is anticipated to reduce pneumonia risk in the

19 population orthogonal to other strategies aimed at reducing infection risk. Since ACE is highly

20 expressed in the lung with adverse effects, such as cough, there were initial concerns about

21 ACEi potentially exacerbating pulmonary diseases or leading to pulmonary infections. The

22 observational association of antihypertensives with increased pneumonia risk is rendered

23 nonsignificant when adjusting for hypertension consistent with confounding by indication. A

24 meta-analysis comprising of randomized controlled and observational studies indicated that

25 ACEi may be protective for pneumonia risk $^{42}$. As detailed earlier, since ACE2 may serve as a

26 receptor for respiratory viral entry and is an endogenous counter-regulator of ACE, conflicting 
medRxiv preprint doi: https://doi.org/10.1101/2020.04.19.20071936; this version posted April 23, 2020. The copyright holder for this preprint (which was not certified by peer review) is the author/funder, who has granted medRxiv a license to display the preprint in perpetuity.

It is made available under a CC-BY 4.0 International license.

1 hypotheses for ACEi and COVID-19 risk have emerged ${ }^{43-45}$. We do not observe that genetic

2 variants influencing the expression of $A C E$ in the lung or kidney significantly increase the risk of

3 pneumonia. Whether genetic variants at ACE have outsized influence on COVID-19 risk

4 requires further study. However, our results are aligned with current recommendations to

5 maintain stable, normal blood pressure, including with ACEi as indicated ${ }^{46} 47$. Consistent with

6 this finding, the Systolic Blood Pressure Intervention Trial (SPRINT) also showed that intensive

7 blood pressure reduction (to a mean SBP of $121 \mathrm{mmHg}$ ) resulted in fewer cases of incident

8 pneumonia (2.1\% versus $2.4 \%$ ) compared to standard blood pressure reduction (to a mean

9 SBP of $136 \mathrm{mmHg})^{48}$. Additionally, a separate multi-center study of 1,128 patients with

10 hypertension diagnosed with COVID-19 showed that inpatient use of ACEi/ARB was associated

11 with lower risk of all-cause mortality compared with ACEi/ARB non-users (HR 0.37, $P=0.03)^{49}$.

12 Thus, withdrawal of ACEi and challenges of blood pressure management while promoting

13 physical distancing, may not only have untoward cardiovascular consequences but may

14 inadvertently increase pneumonia risk.

\section{Strengths and limitations}

18 This study has several strengths, including the analysis of a large, genotyped population-based

19 cohort with high fidelity phenotyping, including with subclinical respiratory phenotypes.

20 Furthermore, diverse phenotyping facilitates extensive individual-level covariate adjustment in

21 the models and sensitivity analyses to assess for pleiotropy. Our overall study design, with the

22 incorporation of Mendelian randomisation, permits more robust causal inference in humans

23 beyond observational prospective analyses. While our study has several strengths, some

24 limitations should be considered. First, the present analyses were conducted among individuals

25 of white British ancestry residing in the UK; whether the present findings generalize to diverse

26 ethnicities and other geographic regions remains to be tested. Second, our model assumes the 
medRxiv preprint doi: https://doi.org/10.1101/2020.04.19.20071936; this version posted April 23, 2020. The copyright holder for this preprint (which was not certified by peer review) is the author/funder, who has granted medRxiv a license to display the preprint in perpetuity.

It is made available under a CC-BY 4.0 International license.

1 association of the genetic instrument to the outcome occurs via the primary exposure and is not

2 confounded by pleiotropy ${ }^{50}{ }^{51}$. We have performed a number of sensitivity analyses to assess for

3 possible confounders, in particular, we observe that our genetic instruments for blood pressure

4 are not associated with key socioeconomic and lifestyle factors influencing both blood pressure

5 and pneumonia risk. We further maintain a sparsely adjusted model in our one-sample

6 Mendelian randomization analyses to reduce the potential for collider bias ${ }^{52}$. Additionally,

7 secondary 2-sample Mendelian randomization analyses provide consistent results with no

8 evidence of horizontal pleiotropy, heterogeneity, or individual variants driving the association.

9 Third, while our results do not yield an association between ACE eQTLs and pneumonia risk,

10 we cannot rule out the possibility of reduced power for this analysis. Fourth, outcomes for the

11 present analyses occurred prior to the COVID-19 pandemic. The first release of COVID-19

12 phenotypes from the UK Biobank participants has few COVID-19 events (approximately 0.1\%),

13 which limits power. Furthermore, with testing data only in $0.3 \%$ of UK Biobank participants,

14 analyses are currently limited by ascertainment bias. Whether the current findings translate to

15 COVID-19 require further verification.

\section{Conclusions:}

20 Our study provides evidence that hypertension directly influences the risk of pneumonia.

21 Vigilance for blood pressure monitoring and management may reduce risk for pneumonia,

22 including potentially for the ongoing COVID-19 pandemic. 
medRxiv preprint doi: https://doi.org/10.1101/2020.04.19.20071936; this version posted April 23, 2020. The copyright holder for this preprint (which was not certified by peer review) is the author/funder, who has granted medRxiv a license to display the preprint in perpetuity.

It is made available under a CC-BY 4.0 International license .

1 Acknowledgments: The authors would like to acknowledge and thank the participants and staff

2 of the UK Biobank and of the ICBP consortium cohorts. This work was supported by UK

3 Biobank application number 7089.

4

Funding: S.M.Z. is supported by the National Institutes of Health's NHLBI under award number 1F30HL149180-01 and the National Institutes of Health's Medical Scientist Training Program at the Yale School of Medicine. M.C.H. is supported by the National Institutes of Health

8 (T32HL094301-07). P.N. is supported by a Hassenfeld Scholar Award from the Massachusetts

9 General Hospital, and grants from the National Heart, Lung, and Blood Institute (R01HL1427,

10 R01HL148565, and R01HL148050) and Fondation Leducq (TNE-18CVD04).

11 Disclosures: P.N. reports investigator-initiated grants from Amgen, Apple, and Boston Scientific, 12 and consulting income from Apple and Blackstone Life Sciences. The remaining authors have 13 nothing to disclose. 
medRxiv preprint doi: https://doi.org/10.1101/2020.04.19.20071936; this version posted April 23, 2020. The copyright holder for this preprint (which was not certified by peer review) is the author/funder, who has granted medRxiv a license to display the preprint in perpetuity.

It is made available under a CC-BY 4.0 International license .

\section{Figure 1: Epidemiological association of prevalent hypertension with respiratory} 2 diseases

3

4

5

6

7

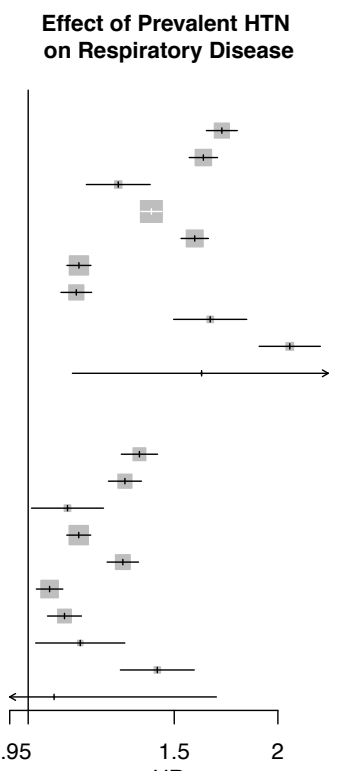

HR $\quad 95 \% \mathrm{Cl}$

$1.71 \quad[1.64 ; 1.79] \quad 4.66 \mathrm{e}-133$

$1.63 \quad[1.56 ; 1.69]$

$1.41 \quad[1.37 ; 1.45]$

$1.59 \quad[1.53 ; 1.65]$

$1.15 \quad[1.11 ; 1.19]$

$1.14 \quad[1.10 ; 1.19]$

$1.66 \quad[1.50 ; 1.83]$

$2.07 \quad[1.90 ; 2.25]$

$1.62 \quad[1.13 ; 2.32]$

$4.94 \mathrm{e}-130$

$3.21 \mathrm{e}-08$

$7.99 \mathrm{e}-115$

$1.44 \mathrm{e}-125$

$1.22 \mathrm{e}-16$

8.17e-10

$1.65 \mathrm{e}-22$

$5.69 \mathrm{e}-63$

0.00853

$[1.29 ; 1.43$

$[1.25 ; 1.37]$

$[1.01 ; 1.23$

$[1.11 ; 1.19]$

$[1.25 ; 1.36]$

$[1.02 ; 1.10]$

$[1.06 ; 1.16]$

$[1.02 ; 1.31]$

$[1.29 ; 1.59]$

[0.68; 1.69]

$2.69 \mathrm{e}-33$

$1.46 \mathrm{e}-30$

0.032

$1.43 \mathrm{e}-16$

$3.22 \mathrm{e}-32$

0.00155

0.0000276

0.022

$7.34 \mathrm{e}-12$

0.75
Incd Cases (N)

Controls (N)

Cases with HTN (N)

Controls with HTN (N)

11,907

2,575

21,644

12,881

18,110

10,915

1,778

160

9,486

11,457

2,521

21,131

12,564

17,805

10,732

1,694

2,460

150
356,687
349,112
367,226
328,513
312,416
308,685
315,009
373,296
372,877
375,580


351,061
343,628
361,108
323,367
307,352
303,562
309,649
367,129
366,754
369,303

8
99,476

97,205

104,184

89,858

85,838

87,314

90,116

105,672

105,400

106,729

97,355

95,139

101,770

87,913

83,951

85,297

87,990

103,259

103,016

104,254

11 Association between prevalent hypertension (HTN) and incident respiratory disease is shown in 12 a sparsely adjusted and fully adjusted model. The sparsely adjusted model is adjusted by age,

13 age $^{2}$, sex, smoking status (current, prior, or never smoker), and the first ten principal

14 components of population stratification. The fully adjusted model is additionally adjusted by

15 prevalent coronary artery disease, prevalent diabetes, and body mass index.

16 HTN $=$ Hypertension, ARDS $=$ Adult respiratory disease syndrome, $\mathrm{HR}=$ hazard ratio 
medRxiv preprint doi: https://doi.org/10.1101/2020.04.19.20071936; this version posted April 23, 2020. The copyright holder for this preprint (which was not certified by peer review) is the author/funder, who has granted medRxiv a license to display the preprint in perpetuity.

It is made available under a CC-BY 4.0 International license .

Figure 2: Epidemiological association of antihypertensive use with incident pneumonia

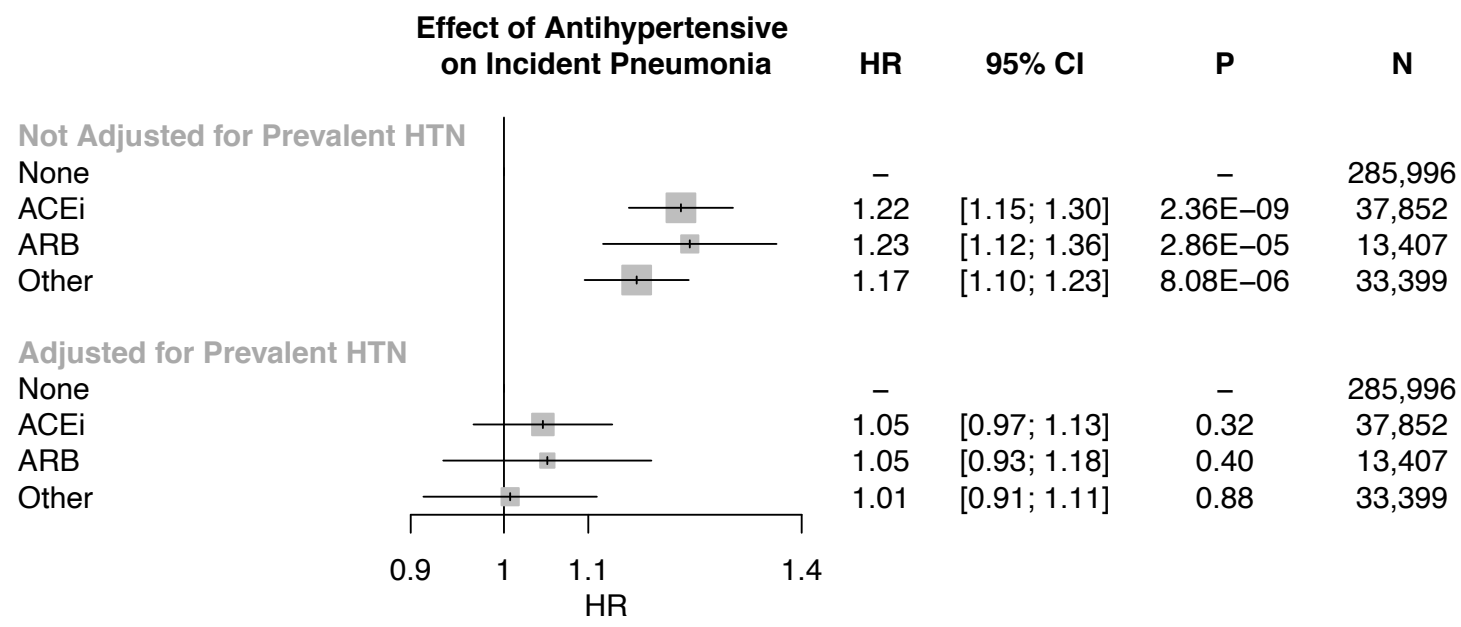

Association of antihypertensive use with incident pneumonia, adjusted by age, age2, sex, smoking status, prevalent coronary artery disease, prevalent diabetes, body mass index, and the first ten principal components of population stratification, displayed with and without adjusting for prevalent hypertension, suggests that the effect of antihypertensives on increased risk of incident pneumonia is driven by hypertensive status.

$9 \mathrm{ACEi}=$ angiotensin converting enzyme inhibitor, $\mathrm{ARB}=$ angiotensin receptor blocker, $\mathrm{HR}=$ 10 hazard ratio 
medRxiv preprint doi: https://doi.org/10.1101/2020.04.19.20071936; this version posted April 23, 2020. The copyright holder for this preprint (which was not certified by peer review) is the author/funder, who has granted medRxiv a license to display the preprint in perpetuity.

It is made available under a CC-BY 4.0 International license .

Figure 3: Genetic association of blood pressure with incident respiratory disease

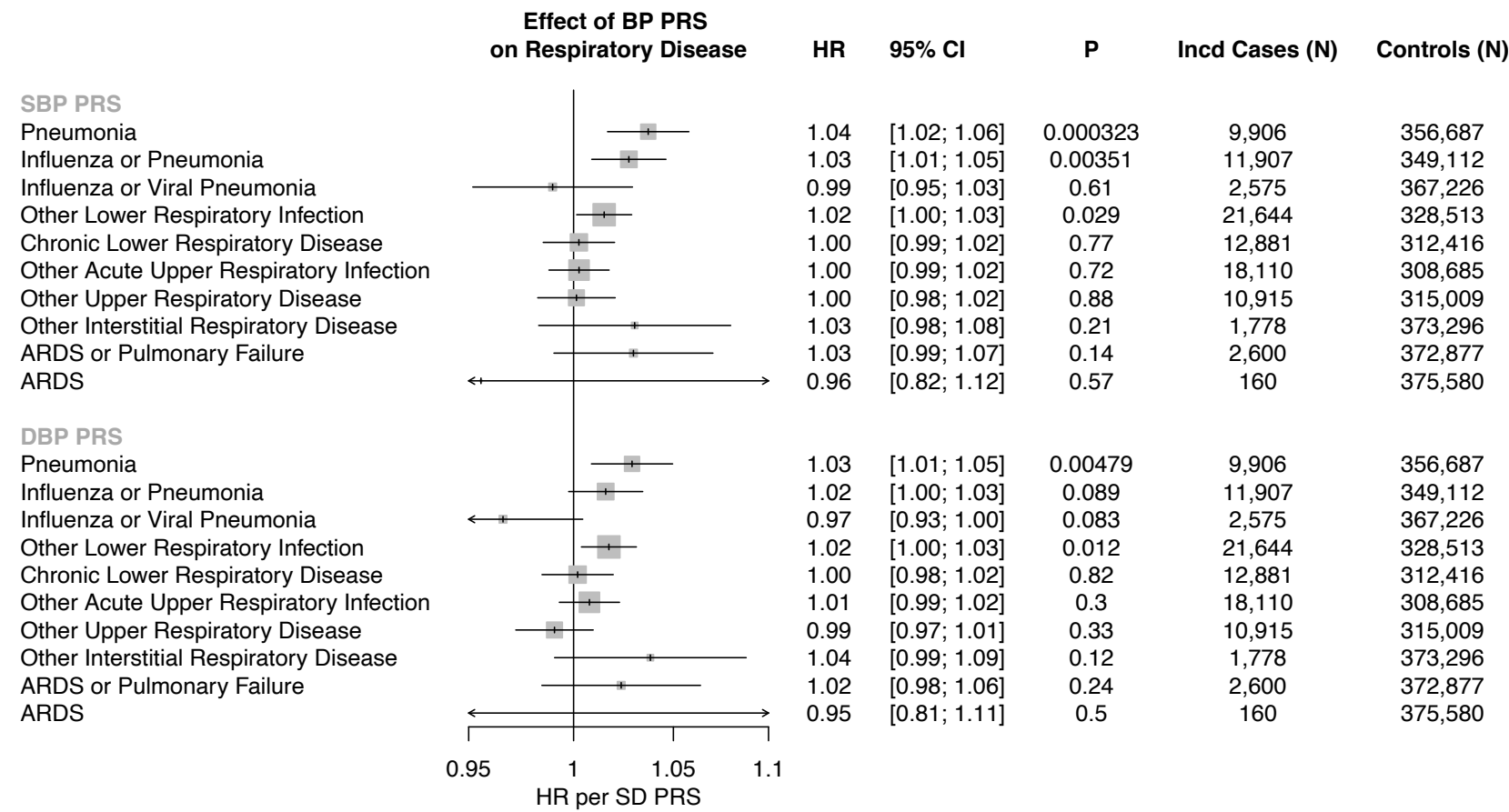

Association of systolic blood pressure polygenic risk score (SBP PRS) and diastolic blood pressure polygenic risk score (DBP PRS) with incident respiratory disease, adjusted for age, $\mathrm{age}^{2}$, sex, smoking status, and the first ten principal components of population stratification in the UK Biobank. Effects are interpreted as hazard ratio (HR) per standard deviation (SD) increase of the respective PRS. Of note, each SD increase in the SBP PRS increases SBP by $2.26 \mathrm{mmHg}$, and each SD increase in the DBP PRS increases DBP by $1.32 \mathrm{mmHg}$ in the UK Biobank. 
medRxiv preprint doi: https://doi.org/10.1101/2020.04.19.20071936; this version posted April 23, 2020. The copyright holder for this preprint (which was not certified by peer review) is the author/funder, who has granted medRxiv a license to display the preprint in perpetuity.

It is made available under a CC-BY 4.0 International license .

\section{Figure 4: Epidemiological and genetic association of elevated blood pressure with} 2 pulmonary function tests

A.

\section{Effect of Prevalent HTN} on PFTs

Beta $\quad 95 \% \mathrm{Cl}$

$\mathbf{P}$

$\mathbf{N}$

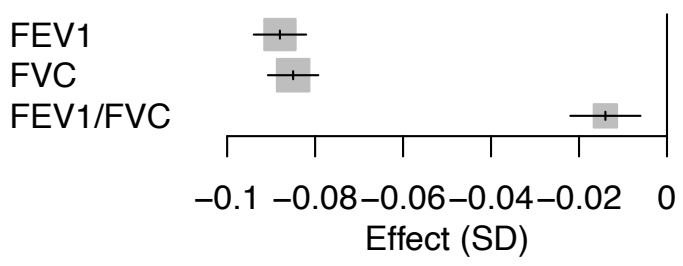

B.

\section{Effect of BP PRS} on PFTs

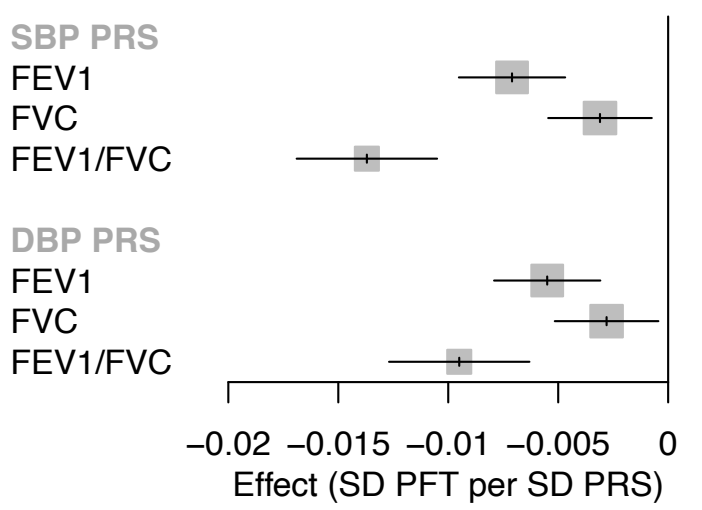

\section{Beta $\quad 95 \% \mathrm{Cl}$}

$-0.007$

$-0.003$

$[-0.010 ;-0.005]$

$[-0.005 ;-0.001]$

$-0.014 \quad[-0.017 ;-0.011]$

$-0.005$

$-0.003$

$-0.009$
$[-0.008 ;-0.003]$
$[-0.005 ; 0.000]$
$[-0.013 ;-0.006]$

$9.14 \mathrm{e}-06$

0.02

$6.18 \mathrm{e}-09$
324,044

324,044

324,044

\footnotetext{
A) Association of prevalent hypertension with pulmonary function tests (PFT), adjusted for age, age2, sex, smoking status, prevalent coronary artery disease, prevalent diabetes, body mass index, and the first ten principal components of population stratification in the UK Biobank. B) Association of systolic blood pressure polygenic risk score (SBP PRS) and diastolic blood pressure polygenic risk score (DBP PRS) with pulmonary function tests (PFT), adjusted for age, age2, sex, smoking status, and the first ten principal components of population stratification in the UK Biobank. Effects are interpreted as SD change in PFT per SD increase of the respective PRS. Of note, each SD increase in the SBP PRS increases SBP by $2.26 \mathrm{mmHg}$, and each SD increase in the DBP PRS increases DBP by $1.32 \mathrm{mmHg}$ in the UK Biobank. FEV1 $=$ Forced expiratory volume in 1-second, FVC = Forced vital capacity, HTN = hypertension, PFT = pulmonary function test
} 
medRxiv preprint doi: https://doi.org/10.1101/2020.04.19.20071936; this version posted April 23, 2020. The copyright holder for this preprint (which was not certified by peer review) is the author/funder, who has granted medRxiv a license to display the preprint in perpetuity.

It is made available under a CC-BY 4.0 International license .

\section{$\underline{\text { References: }}$}

1. Olsen MH, Angell SY, Asma S, et al. A call to action and a lifecourse strategy to address the global burden of raised blood pressure on current and future generations: the Lancet Commission on hypertension. Lancet 2016;388(10060):2665-712. doi: 10.1016/S01406736(16)31134-5 [published Online First: 2016/09/28]

2. Shen Y, Chen Y, Huang Z, et al. Associations between untraditional risk factors, pneumonia/lung cancer, and hospital fatality among hypertensive men in Guangzhou downtown. Sci Rep 2020;10(1):1425. doi: 10.1038/s41598-020-58207-z [published Online First: 2020/01/31]

3. Okaishi K, Morimoto S, Fukuo K, et al. Reduction of risk of pneumonia associated with use of angiotensin I converting enzyme inhibitors in elderly inpatients. Am J Hypertens 1999;12(8 Pt 1):778-83. doi: 10.1016/s0895-7061(99)00035-7 [published Online First: 1999/09/10]

4. Huang C, Wang Y, Li X, et al. Clinical features of patients infected with 2019 novel coronavirus in Wuhan, China. Lancet 2020;395(10223):497-506. doi: 10.1016/S01406736(20)30183-5 [published Online First: 2020/01/28]

5. Wang C, Liu L, Hao X, et al. Evolving Epidemiology and Impact of Non-pharmaceutical Interventions on the Outbreak of Coronavirus Disease 2019 in Wuhan, China. medRxiv 2020:2020.03.03.20030593. doi: 10.1101/2020.03.03.20030593

6. Wang Z, Yang B, Li Q, et al. Clinical Features of 69 Cases with Coronavirus Disease 2019 in Wuhan, China. Clin Infect Dis 2020 doi: 10.1093/cid/ciaa272 [published Online First: 2020/03/17]

7. Wu C, Chen X, Cai Y, et al. Risk Factors Associated With Acute Respiratory Distress Syndrome and Death in Patients With Coronavirus Disease 2019 Pneumonia in Wuhan, China. JAMA Intern Med 2020 doi: 10.1001/jamainternmed.2020.0994 [published Online First: 2020/03/14]

8. Wosten-van Asperen RM, Lutter R, Haitsma JJ, et al. ACE mediates ventilator-induced lung injury in rats via angiotensin II but not bradykinin. Eur Respir J 2008;31(2):363-71. doi: 10.1183/09031936.00060207 [published Online First: 2007/10/26]

9. Marshall RP, Webb S, Bellingan GJ, et al. Angiotensin converting enzyme insertion/deletion polymorphism is associated with susceptibility and outcome in acute respiratory distress syndrome. Am J Respir Crit Care Med 2002;166(5):646-50. doi: 10.1164/rccm.2108086 [published Online First: 2002/09/03]

10. Kuba K, Imai Y, Rao S, et al. A crucial role of angiotensin converting enzyme 2 (ACE2) in SARS coronavirus-induced lung injury. Nat Med 2005;11(8):875-9. doi: 10.1038/nm1267 [published Online First: 2005/07/12]

11. Yang $\mathrm{P}, \mathrm{Gu} \mathrm{H}, \mathrm{Zhao} \mathrm{Z}$, et al. Angiotensin-converting enzyme 2 (ACE2) mediates influenza H7N9 virus-induced acute lung injury. Sci Rep 2014;4:7027. doi: 10.1038/srep07027 [published Online First: 2014/11/14]

12. Gu H, Xie Z, Li T, et al. Angiotensin-converting enzyme 2 inhibits lung injury induced by respiratory syncytial virus. Sci Rep 2016;6:19840. doi: 10.1038/srep19840 [published Online First: 2016/01/28]

13. Sodhi CP, Nguyen J, Yamaguchi Y, et al. A Dynamic Variation of Pulmonary ACE2 Is Required to Modulate Neutrophilic Inflammation in Response to Pseudomonas aeruginosa Lung Infection in Mice. J Immunol 2019;203(11):3000-12. doi: 10.4049/jimmunol.1900579 [published Online First: 2019/10/28] 
medRxiv preprint doi: https://doi.org/10.1101/2020.04.19.20071936; this version posted April 23, 2020. The copyright holder for this preprint (which was not certified by peer review) is the author/funder, who has granted medRxiv a license to display the preprint in perpetuity.

It is made available under a CC-BY 4.0 International license .

14. Davies NM, Holmes MV, Davey Smith G. Reading Mendelian randomisation studies: a guide, glossary, and checklist for clinicians. $B M J$ 2018;362:k601. doi: 10.1136/bmj.k601 [published Online First: 2018/07/14]

15. Evangelou E, Warren HR, Mosen-Ansorena D, et al. Genetic analysis of over 1 million people identifies 535 new loci associated with blood pressure traits. Nat Genet 2018;50(10):1412-25. doi: 10.1038/s41588-018-0205-x [published Online First: 2018/09/19]

16. Bycroft C, Freeman C, Petkova D, et al. The UK Biobank resource with deep phenotyping and genomic data. Nature 2018;562(7726):203-09. doi: 10.1038/s41586-018-0579-z [published Online First: 2018/10/12]

17. McCarthy S, Das S, Kretzschmar W, et al. A reference panel of 64,976 haplotypes for genotype imputation. Nat Genet 2016;48(10):1279-83. doi: 10.1038/ng.3643 [published Online First: 2016/08/23]

18. Bycroft C, Freeman C, Petkova D, et al. Genome-wide genetic data on $\sim 500,000$ UK Biobank participants. bioRxiv 2017 doi: 10.1101/166298

19. Zekavat SM, Aragam K, Emdin C, et al. Genetic Association of Finger Photoplethysmography-Derived Arterial Stiffness Index With Blood Pressure and Coronary Artery Disease. Arterioscler Thromb Vasc Biol 2019;39(6):1253-61. doi: 10.1161/ATVBAHA.119.312626 [published Online First: 2019/05/10]

20. Warren HR, Evangelou E, Cabrera CP, et al. Genome-wide association analysis identifies novel blood pressure loci and offers biological insights into cardiovascular risk. Nat Genet 2017;49(3):403-15. doi: 10.1038/ng.3768 [published Online First: 2017/01/31]

21. Tobin MD, Sheehan NA, Scurrah KJ, et al. Adjusting for treatment effects in studies of quantitative traits: antihypertensive therapy and systolic blood pressure. Stat Med 2005;24(19):2911-35. doi: 10.1002/sim.2165 [published Online First: 2005/09/10]

22. Townsend P, Phillimore P., Beattie A. Health and deprivation. Inequality and the North. Health Policy 1989;10(2)

23. Yavorska OO, Burgess S. MendelianRandomization: an R package for performing Mendelian randomization analyses using summarized data. Int J Epidemiol 2017;46(6):1734-39. doi: 10.1093/ije/dyx034 [published Online First: 2017/04/12]

24. Burgess S, Bowden J, Dudbridge F, et al. Robust instrumental variable methods using multiple candidate instruments with application to Mendelian randomization. ArXiv eprints 2016. https://ui.adsabs.harvard.edu/\#abs/2016arXiv160603729B (accessed June 01, 2016).

25. Zhao QW, J.; Hemani, G.; Bowden, J.; Small S.D. Statistical inference in two-sample summary-data Mendelian randomization using robust adjusted profile score. ArXiveprints 2018(1801.09652)

26. Hemani G, Tilling K, Davey Smith G. Orienting the causal relationship between imprecisely measured traits using GWAS summary data. PLoS Genet 2017;13(11):e1007081. doi: 10.1371/journal.pgen.1007081 [published Online First: 2017/11/18]

27. Consortium GT, Laboratory DA, Coordinating Center -Analysis Working G, et al. Genetic effects on gene expression across human tissues. Nature 2017;550(7675):204-13. doi: 10.1038/nature24277 [published Online First: 2017/10/13]

28. Shen Y, Tian Z, Lu D, et al. Impact of pneumonia and lung cancer on mortality of women with hypertension. Sci Rep 2016;6(1):20. doi: 10.1038/s41598-016-0023-2 [published Online First: 2017/04/27] 
29. Guzik TJ, Hoch NE, Brown KA, et al. Role of the T cell in the genesis of angiotensin II induced hypertension and vascular dysfunction. J Exp Med 2007;204(10):2449-60. doi: 10.1084/jem.20070657 [published Online First: 2007/09/19]

30. Wenzel P, Knorr M, Kossmann S, et al. Lysozyme M-positive monocytes mediate angiotensin II-induced arterial hypertension and vascular dysfunction. Circulation 2011;124(12):1370-81. doi: 10.1161/CIRCULATIONAHA.111.034470 [published Online First: 2011/08/31]

31. Morton J, Coles B, Wright K, et al. Circulating neutrophils maintain physiological blood pressure by suppressing bacteria and IFNgamma-dependent iNOS expression in the vasculature of healthy mice. Blood 2008;111(10):5187-94. doi: 10.1182/blood-2007-10117283 [published Online First: 2008/02/19]

32. Siedlinski M, Jozefczuk E, Xu X, et al. White Blood Cells and Blood Pressure: A Mendelian Randomization Study. Circulation 2020 doi: 10.1161/CIRCULATIONAHA.119.045102 [published Online First: 2020/03/10]

33. Speyer CL, Neff TA, Warner RL, et al. Regulatory effects of iNOS on acute lung inflammatory responses in mice. Am J Pathol 2003;163(6):2319-28. doi: 10.1016/S00029440(10)63588-2 [published Online First: 2003/11/25]

34. Selemidis S, Seow HJ, Broughton BR, et al. Nox1 oxidase suppresses influenza a virusinduced lung inflammation and oxidative stress. PLoS One 2013;8(4):e60792. doi: 10.1371/journal.pone.0060792 [published Online First: 2013/04/12]

35. Jankowich MD, Taveira T, Wu WC. Decreased lung function is associated with increased arterial stiffness as measured by peripheral pulse pressure: data from NHANES III. Am J Hypertens 2010;23(6):614-9. doi: 10.1038/ajh.2010.37 [published Online First: 2010/03/13]

36. Amaral AF, Patel J, Gnatiuc L, et al. Association of pulse wave velocity with total lung capacity: A cross-sectional analysis of the BOLD London study. Respir Med 2015;109(12):1569-75. doi: 10.1016/j.rmed.2015.10.016 [published Online First: 2015/11/11]

37. Duprez DA, Hearst MO, Lutsey PL, et al. Associations among lung function, arterial elasticity, and circulating endothelial and inflammation markers: the multiethnic study of atherosclerosis. Hypertension 2013;61(2):542-8. doi: 10.1161/HYPERTENSIONAHA.111.00272 [published Online First: 2013/01/04]

38. Mullerova H, Agusti A, Erqou S, et al. Cardiovascular comorbidity in COPD: systematic literature review. Chest 2013;144(4):1163-78. doi: 10.1378/chest.12-2847 [published Online First: 2013/06/01]

39. Zhu Z, Wang X, Li X, et al. Genetic overlap of chronic obstructive pulmonary disease and cardiovascular disease-related traits: a large-scale genome-wide cross-trait analysis. Respir Res 2019;20(1):64. doi: 10.1186/s12931-019-1036-8 [published Online First: 2019/04/04]

40. Iyer KS, Newell JD, Jr., Jin D, et al. Quantitative Dual-Energy Computed Tomography Supports a Vascular Etiology of Smoking-induced Inflammatory Lung Disease. Am J Respir Crit Care Med 2016;193(6):652-61. doi: 10.1164/rccm.201506-1196OC [published Online First: 2015/11/17]

41. Barnes PJ. Inflammatory mechanisms in patients with chronic obstructive pulmonary disease. J Allergy Clin Immunol 2016;138(1):16-27. doi: 10.1016/j.jaci.2016.05.011 [published Online First: 2016/07/05] 
medRxiv preprint doi: https://doi.org/10.1101/2020.04.19.20071936; this version posted April 23, 2020. The copyright holder for this preprint (which was not certified by peer review) is the author/funder, who has granted medRxiv a license to display the preprint in perpetuity.

It is made available under a CC-BY 4.0 International license .

42. Caldeira D, Alarcao J, Vaz-Carneiro A, et al. Risk of pneumonia associated with use of angiotensin converting enzyme inhibitors and angiotensin receptor blockers: systematic review and meta-analysis. $B M J$ 2012;345:e4260. doi: 10.1136/bmj.e4260 [published Online First: 2012/07/13]

43. Fang L, Karakiulakis G, Roth M. Are patients with hypertension and diabetes mellitus at increased risk for COVID-19 infection? Lancet Respir Med 2020;8(4):e21. doi: 10.1016/S2213-2600(20)30116-8 [published Online First: 2020/03/15]

44. Vaduganathan M, Vardeny O, Michel T, et al. Renin-Angiotensin-Aldosterone System Inhibitors in Patients with Covid-19. N Engl J Med 2020 doi: 10.1056/NEJMsr2005760 [published Online First: 2020/04/01]

45. Danser AHJ, Epstein M, Batlle D. Renin-Angiotensin System Blockers and the COVID-19 Pandemic: At Present There Is No Evidence to Abandon Renin-Angiotensin System Blockers. Hypertension 2020:HYPERTENSIONAHA12015082. doi: 10.1161/HYPERTENSIONAHA.120.15082 [published Online First: 2020/03/27]

46. Boszhurt BKRHB. HFSA/ACC/AHA statement addresses concerns re: using RAAS antagonists in COVID-19: AHA Science News; 2020 [Available from: https://professional.heart.org/professional/ScienceNews/UCM 505836_HFSAACCAHA statement-addresses-concerns-re-using-RAAS-antagonists-in-COVID.jsp.

47. G. S. Position Statement of the ESC Council on Hypertension on ACE-Inhibitors and Angiotensin Receptor Blockers: European Society of Cardiology; 2020 [Available from: https://www.escardio.org/Councils/Council-on-Hypertension-(CHT)/News/positionstatement-of-the-esc-council-on-hypertension-on-ace-inhibitors-and-ang.

48. Group SR, Wright JT, Jr., Williamson JD, et al. A Randomized Trial of Intensive versus Standard Blood-Pressure Control. N Engl J Med 2015;373(22):2103-16. doi: 10.1056/NEJMoa1511939 [published Online First: 2015/11/10]

49. Zhang P, Zhu L, Cai J, et al. Association of Inpatient Use of Angiotensin Converting Enzyme Inhibitors and Angiotensin II Receptor Blockers with Mortality Among Patients With Hypertension Hospitalized With COVID-19. Circ Res 2020 doi: 10.1161/CIRCRESAHA.120.317134 [published Online First: 2020/04/18]

50. Holmes MV, Ala-Korpela M, Smith GD. Mendelian randomization in cardiometabolic disease: challenges in evaluating causality. Nat Rev Cardiol 2017;14(10):577-90. doi: 10.1038/nrcardio.2017.78 [published Online First: 2017/06/02]

51. Bennett DA, Holmes MV. Mendelian randomisation in cardiovascular research: an introduction for clinicians. Heart 2017;103(18):1400-07. doi: 10.1136/heartjnl-2016310605 [published Online First: 2017/06/10]

52. Paternoster L, Tilling K, Davey Smith G. Genetic epidemiology and Mendelian randomization for informing disease therapeutics: Conceptual and methodological challenges. PLoS Genet 2017;13(10):e1006944. doi: 10.1371/journal.pgen.1006944 [published Online First: 2017/10/06] 